\title{
The effect of disinfectants on fungal diseases of cucumber
}

\author{
HanNa AVIKainen, HilkKa Koponen and Risto TAHVONEN
}

\begin{abstract}
Avikainen, H., Koponen, H. \& Tahyonen, R. 1993. The effect of disinfectants on fungal diseases of cucumber. Agric. Sci. Finl. 2: 179-188. (Dept. Pl. Biol., P.O.Box 28, FIN-00014 University of Helsinki, Finland and Agric. Res. Centre of Finland, Inst. PI. Protect., FIN-31600 Jokioinen, Finland.)

Formaline, Iobac $\mathrm{P}$, sodium hypochlorite $(\mathrm{NaOCl})$, Korsolin and Menno-Ter-forte were effective disinfectants in the control of damping-off (Pythium sp.) from peat substrate. Ipasept, Sanisept and Virkon S $(1 \%)$ were shown ineffective against Pythium sp. in peat. Only formaline was effective in the control of black root rot (Phomopsis sclerotioides) from peat. In sand substrate $P$. sclerotioides could be eradicated also with sodium hypochlorite. Verticillium wilt (Verticillium dahliae) from peat substrate could be controlled with formaline, Iobac P, sodium hypochlorite and Virkon S. Formaline and sodium hypochlorite were effective against Verticillium wilt in sand. Black stem rot (Didymella bryoniae) was susceptible to all disinfectants tested.
\end{abstract}

Key words: Didymella bryoniae, disinfection, Phomopsis sclerotioides, Pythium sp., Verticillium dahliae

\section{Introduction}

The production of cucumber starts in Finland by growing seedlings in artificial light at the end of December. The greenhouses must be clean and free of diseases and pests in order to get high quality seedlings. Either new peat or rock wool is used as seedling growth substrate. One of the major risks is the damping-off. The cultivation is continued at the end of January in normal greenhouse conditions using as growth substrate rock wool or new peat isolated from ground soil with a plastic sheet or plastic bags. The major diseases are various root diseases and stem and leaf diseases during the growing season. Therefore the growing places must be free from diseases and pests before planting the seedlings. It is very common that farmers change plants during the summer to get a higher yield and a better quality in autumn. The risk of severe dis- ease infection is great, because diseases may spread with plant debris from old to new plants.

Pythium sp., which causes damping-off, is a major problem in cucumber cultivation in Finland. Also black stem rot (Didymella bryoniae) is common and difficult to control. Black root rot (Phomopsis sclerotioides) and Verticillium wilt (Verticillium dahliae) are severe diseases of cucumber (FLETCHER 1984). Black root rot is a very common disease on cucumber in Finland (MURMAN 1992). Verticillium wilt causes losses in open fields in southwestern Finland and in some cases in greenhouses in western Finland (TAHVONEN 1987). There are no resistant cultivars or effective fungicides to control these diseases.

Disinfection of the soil has previously been investigated as a means to control fungi (LINNASALMI 1955). Today, the growth substrate is changed every year (MURMAN 1992), which makes 
Table 1. The disinfectants, their active substances and the concentrations recommended by the manufacturers.

\begin{tabular}{|c|c|c|}
\hline Disinfectant & Active ingredient, \% & $\begin{array}{c}\text { Recommended } \\
\text { concentration, \% }\end{array}$ \\
\hline Desinfektol EL & Ethanol, 60 & undiluted \\
\hline Formaline & Formaldehyde, 37 & 5.0 \\
\hline Iobac P & Iodine, 1.8 & 3.0 \\
\hline Ipasept & $\begin{array}{l}\text { Quaternary ammo- } \\
\text { nium compounds, } 2.8\end{array}$ & 2.0 \\
\hline Korsolin & Glutaraldehyde, 10 & 1.0 \\
\hline Menno-Ter-forte & $\begin{array}{l}\text { Quaternary ammo- } \\
\text { nium compounds, } 32.5\end{array}$ & 1.0 \\
\hline Sanisept & $\begin{array}{l}\text { Quaternary ammo- } \\
\text { nium compounds, } 2.5\end{array}$ & 2.0 \\
\hline $\begin{array}{l}\text { Sodium hypo- } \\
\text { chlorite (NaOCl) }\end{array}$ & Active chlorine, 10 & 10.0 \\
\hline Taloset & $\begin{array}{l}\text { Quaternary ammo- } \\
\text { nium compounds, } 3.5\end{array}$ & 2.0 \\
\hline Virkon S & $\begin{array}{l}\text { Potassium peroxysul- } \\
\text { phate, } 60\end{array}$ & 1.0 \\
\hline
\end{tabular}

disinfection of soil unnecessary. The pathogens do, however, survive in plant debris and in soil particles as well as in the greenhouse structures for a long time. Disinfection of the structures and equipment is therefore still necessary.

This disinfection study was carried out in 19881990 to establish the applicability of different disinfectants in plant production and their effect on fungal pathogens of cucumber. The research is part of a study carried out jointly by the University of Helsinki, the Technical Research Centre of Finland and the Agricultural Research Centre.

\section{Material and methods}

\section{Disinfectants and fungi}

Ten commercial disinfectants were tested on fungal pathogens of cucumber (Table 1). The concentrations recommended by the manufacturers were used in the trials. Any deviations from these concentrations are given in the tables. The disinfectants were diluted in tap water.

The tested fungi were Didymella bryoniae, Phomopsis sclerotioides, Pythium sp. and Verticillium dahliae. The names of the fungi are according to
Table 2. The growth media used in the fungal cultures.

\begin{tabular}{|c|c|}
\hline Fungus & Growth medium \\
\hline Didymella bryoniae & $\begin{array}{l}\text { Corn meal agar }(\text { Difco })+100 \mathrm{ppm} \\
\text { streptomycin sulphate }\end{array}$ \\
\hline \multirow[t]{2}{*}{ Phomopsis sclerotioides } & Malt extract agar (Difco) \\
\hline & $\begin{array}{l}\text { Corn meal agar (Difco) }+100 \mathrm{ppm} \\
\text { streptomycin sulphate }\end{array}$ \\
\hline Pythium sp. & Martin's medium \\
\hline Verticillium dahliae & $\begin{array}{l}\text { Corn meal agar (Difco) }+100 \mathrm{ppm} \\
\text { streptomycin sulphate }\end{array}$ \\
\hline
\end{tabular}

DomsCH et al. (1980). The fungal isolates included in the study were obtained the collections of the Institute of Plant Protection of the Agricultural Research Centre. The fungi were cultivated on different media depending on the fungus (Table 2). The formulas for culture media of fungi are presented in BоOTH (1971).

\section{The effect of disinfectants on Pythium, Didymella and Verticillium in peat and plant debris in laboratory experiments}

The effect of concentration and disinfection time in the control of cucumber pathogens in peat and plant debris was investigated in laboratory trials. In testing Pythium sp. and $V$. dahliae the method used for testing the effect of disinfectants on Fusarium culmorum and $F$. oxysporum in peat was used (KoPONEN et al. 1993). However, the amount of peat mixed in disinfectant was $1 \mathrm{~g}$ and $5 \mathrm{~g}$ in the $V$. dahliae trial and the exposure time was 15 and 60 $\mathrm{min}$. In the $D$. bryoniae trial, the inoculate used was obtained by mixing five infected pieces (about $5 \mathrm{~cm}$ long) of cucumber stem and $200 \mathrm{ml}$ of disinfection dilution $\left(\mathrm{N}\right.$ and $\left.10^{-1} \mathrm{~N}\right)$ with a homogenizer. The disinfectants were allowed to act for 10 and 100 min. Filtering and fungal cultivation were carried out as above in the Pythium and V. dahliae experiments.

The effect of the disinfectants on $D$. bryoniae, Pythium sp. and $V$. dahliae on plastic surfaces contaminated with fungus-peat or plant debris mixture was investigated in a laboratory trial. The trial was carried out as described in KOPONEN et al. (1993), 
testing the effect of disinfectants on Fusarium culmorum and Botrytis cinerea on polyethene surface.

All the above trials were made with three replicates. The plates were evaluated after one and three weeks. The results were calculated as efficiency percentages, i.e. the proportion of healthy pieces on agar plates of all pieces.

\section{The effect of disinfectants on pathogens in greenhouse experiments}

\section{Peat experiment on Pythium}

In the Pythium trial, the plastic pots were contaminated by growing in them infected cucumber seedlings for 5 weeks. The cucumber seedlings were inoculated with naturally infected Pythium peat (20 g oat flour/1 l peat). When the seedlings were infected and started to wilt, the growth substrates were allowed to dry. The pots were emptied and the dry peat debris (1-2 g) was washed with disinfection solution using a brush and a propane sprayer (pressure of $4 \mathrm{bar}$ ). After $30 \mathrm{~min}$ the wash suspension $(300-400 \mathrm{ml})$ was filtered. The filter paper with peat was mixed in $200 \mathrm{ml}$ of water with a homogenizer and the mixture was used for biotests.

In the biotest, cucumber seedlings cv. 'Daleva' (7 days old) were used as test plants. The mixture $(10 \mathrm{ml})$ was applied onto the oat-peat collar around the base of the seedlings. The first 24 hours the cucumbers were kept in the dark at $+12-15^{\circ} \mathrm{C}$, thereafter at $20^{\circ} \mathrm{C}$ in greenhouse with a light period of 12 hours (BOUHOT $1975 \mathrm{a}, \mathrm{b}$ ). There were four replicates, with five seedlings per treatment. Observations on the infected and dead plants were made daily four days after the treatments. The cucumbers were grown for 15 days. At the end of the trial the damage caused to the seedling and the roots was evaluated on a rating scale of $0-3$ : $0=$ healthy plant, $1=$ slightly infected base, $2=$ off-white and browned roots, and severely browned base, $3=$ wilted seedling and dead roots. The efficiency percentage of the disinfectants was calculated by comparing the severity of damage to the healthy and affected control using the formula: efficiency $\%=\frac{c-b}{a-b} \cdot 100$

$a=$ severity of infection in healthy control

$\mathrm{b}=$ severity of infection in water control

$\mathrm{c}=$ severity of infection in disinfection treatment.

\section{Peat experiment on Phomopsis and Verticillium}

The effect of disinfectants on P. sclerotioides and $V$. dahliae in peat was investigated by mixing 100 $\mathrm{ml}$ of fungus-peat (one Petri dish culture of fungi/100 ml water/1 l peat) inoculate in 21 of diluted disinfectant. The disinfection solution with peat was filtered after $60 \mathrm{~min}$ and the peat was rinsed twice with water. Treated peat $(3 \mathrm{~g})$ was placed on the bottom of the pots. The pots (1 l) were filled with clean peat. As test plants were used two-day-old pregerminated cucumber seeds which were grown for 4-6 weeks, or one-week-old seedlings grown until fruit production (about 10 weeks). The number of replications was three with three plants per treatment.

At the end of the trial the severity of damage in the shoots and roots was evaluated on a rating scale of 0-3: $0=$ healthy, $1=$ slightly infected base and roots, $2=$ partly wilted leaves and roots, $3=$ dead plant. The efficiency percentage was calculated from the mean of the trials, comparing the effect of the disinfectants on the healthy and infected control like in the Pythium trial.

The viability of $V$. dahliae on the cucumber stem was determined in laboratory. Pieces $(5 \mathrm{~cm})$ were taken from the base of the shoot. From these pieces were cut small pieces $(0.5 \mathrm{~cm})$ and placed on corn meal-streptomycin medium, four pieces per plate, and three plates per plant. The fungi grown on the pieces were evaluated after one and three weeks. The efficiency percentage was calculated as the proportion of healthy pieces of all pieces.

\section{Sand experiment on Phomopsis and Verticillium}

The effect of the disinfectants on $P$. sclerotioides and $V$. dahliae in sand was also investigated. The sand was inoculated by mixing fungal suspension (one fungus culture/100 ml water) in 11 of sand. 
Table 3. The effect of concentration and disinfection time on Pythium sp. in peat debris. Disinfectants and concentrations $(\mathrm{N})$ : $1=$ formaline $(5 \%), 2=\operatorname{Iobac} P(3 \%), 3=\operatorname{Ipasept}(2 \%), 4=$ Korsolin $(1 \%), 5=$ Menno-Ter-forte $(1 \%), 6=\mathrm{NaOCl}(10 \%)$ and $7=$ Virkon $\mathrm{S}(2 \%)$.

\begin{tabular}{|c|c|c|c|c|c|c|c|c|c|}
\hline \multirow{2}{*}{$\begin{array}{l}\text { Concen- } \\
\text { tration of } \\
\text { disinfectant }\end{array}$} & \multirow{2}{*}{$\begin{array}{c}\text { Peat } \\
\mathrm{g} / 11 \\
\text { disinfectant }\end{array}$} & \multirow{2}{*}{$\begin{array}{r}\text { Time, } \\
\text { min }\end{array}$} & \multicolumn{6}{|c|}{ Disinfectant } & \multirow[b]{2}{*}{7} \\
\hline & & & 1 & 2 & 3 & 4 & 5 & 6 & \\
\hline & & \multicolumn{8}{|c|}{ Efficiency \% } \\
\hline \multirow[t]{6}{*}{ Concentration $(\mathrm{N})$} & 1 & 1 & 42 & 100 & 100 & 100 & 100 & 100 & 92 \\
\hline & & 10 & 92 & 100 & 100 & 100 & 100 & 100 & 100 \\
\hline & & 100 & 100 & 100 & 100 & 100 & 100 & 100 & 100 \\
\hline & 0.1 & 1 & 58 & 100 & 100 & 100 & 100 & 100 & 100 \\
\hline & & 10 & 100 & 100 & 100 & 100 & 100 & 100 & 100 \\
\hline & & 100 & 100 & 100 & 100 & 100 & 100 & 100 & 100 \\
\hline \multirow[t]{6}{*}{$10^{-1} \mathrm{~N}$} & 1 & 1 & - & 92 & 100 & 0 & 100 & 16 & 67 \\
\hline & & 10 & - & 100 & 100 & 0 & 100 & 63 & 92 \\
\hline & & 100 & - & 100 & 100 & 92 & 100 & 91 & 100 \\
\hline & 0.1 & 1 & - & 100 & 100 & 100 & 100 & 83 & 100 \\
\hline & & 10 & - & 100 & 67 & 100 & 100 & 100 & 100 \\
\hline & & 100 & & 100 & 92 & 100 & 100 & 100 & 100 \\
\hline
\end{tabular}

Table 4. The effect of concentration and disinfection time on Verticillium dahliae in peat debris. Disinfectants and concentrations $(\mathrm{N}): 1=$ formaline $(5 \%), 2=\operatorname{Iobac} \mathrm{P}(3 \%), 3=\operatorname{Ipasept}(2 \%), 4=$ Menno-Ter-forte $(1 \%), 5=\mathrm{NaOCl}(10 \%), 6=$ Taloset $(3 \%), 7=$ Virkon S $(2 \%)$.

\begin{tabular}{|c|c|c|c|c|c|c|c|c|c|}
\hline \multirow{2}{*}{$\begin{array}{l}\text { Concen- } \\
\text { tration of } \\
\text { disinfectant }\end{array}$} & \multirow{2}{*}{$\begin{array}{c}\text { Peat } \\
\mathrm{g} / 11 \\
\text { disinfectant }\end{array}$} & \multirow[b]{2}{*}{$\min$} & \multirow[b]{2}{*}{1} & \multirow[b]{2}{*}{2} & \multirow[b]{2}{*}{3} & \multicolumn{3}{|c|}{ Time, Disinfectant } & \multirow[b]{2}{*}{7} \\
\hline & & & & & & 4 & 5 & 6 & \\
\hline & & \multicolumn{8}{|c|}{ Efficiency \% } \\
\hline \multirow[t]{2}{*}{ Concentration $(\mathrm{N})$} & 5 & $\begin{array}{l}15 \\
60\end{array}$ & $\begin{array}{l}100 \\
100\end{array}$ & $\begin{array}{r}0 \\
50\end{array}$ & $\begin{array}{l}0 \\
0\end{array}$ & $\begin{array}{l}42 \\
92\end{array}$ & $\begin{array}{l}17 \\
58\end{array}$ & $\begin{array}{l}17 \\
17\end{array}$ & $\begin{array}{l}67 \\
92\end{array}$ \\
\hline & 1 & $\begin{array}{l}15 \\
60\end{array}$ & $\begin{array}{l}75 \\
92\end{array}$ & $\begin{array}{r}33 \\
8\end{array}$ & $\begin{array}{l}8 \\
0\end{array}$ & $\begin{array}{l}25 \\
92\end{array}$ & $\begin{array}{l}50 \\
92\end{array}$ & $\begin{array}{l}0 \\
0\end{array}$ & $\begin{array}{r}92 \\
100\end{array}$ \\
\hline \multirow[t]{2}{*}{$10^{-1} \mathrm{~N}$} & 5 & $\begin{array}{l}15 \\
60\end{array}$ & $\begin{array}{l}100 \\
100\end{array}$ & $\begin{array}{l}0 \\
0\end{array}$ & $\begin{array}{l}0 \\
0\end{array}$ & $\begin{array}{l}0 \\
0\end{array}$ & $\begin{array}{l}0 \\
0\end{array}$ & $\begin{array}{l}0 \\
0\end{array}$ & $\begin{array}{l}92 \\
67\end{array}$ \\
\hline & 1 & $\begin{array}{l}15 \\
60\end{array}$ & $\begin{array}{r}67 \\
100\end{array}$ & $\begin{array}{l}0 \\
0\end{array}$ & $\begin{array}{l}0 \\
0\end{array}$ & $\begin{array}{r}0 \\
17\end{array}$ & $\begin{array}{l}0 \\
8\end{array}$ & $\begin{array}{l}0 \\
0\end{array}$ & $\begin{array}{l}67 \\
42\end{array}$ \\
\hline
\end{tabular}

One litre of inoculated sand was put into plastic pots and $60 \mathrm{ml}$ (approx. $4 \mathrm{l} / \mathrm{m}^{2}$ ) of disinfection dilution was sprayed onto the sand surface. After one hour of treatment the sand was washed with water and filtered. The holes in the peat substrate were filled with $30 \mathrm{~g}$ of treated sand and the oneweek-old cucumber seedlings were planted there. The number of replications was three or five with three seedlings per treatment.
At the end of the trial (3-5 weeks) the severity of damage to shoots and roots was evaluated as above in the peat experiment on Phomopsis. The trial was repeated three times on $P$. sclerotioides and twice on $V$. dahliae. The results were calculated in the same way as in the peat trials on Pythium.

Analysis of variance was used in the statistical analysis of the results. Significances were tested with Tukey's test. 
Table 5. The effect of disinfectants on Didymella bryoniae in cucumber debris.

\begin{tabular}{lrrr}
\hline Treatment & $\begin{array}{c}\text { Concentration } \\
\%\end{array}$ & \multicolumn{2}{c}{ Disinfection time, min } \\
& & \multicolumn{2}{c}{ Efficiency \% } \\
& & 0 & 0 \\
Water & 1 & 83 & 92 \\
Iobac P & 0.1 & 0 & 0 \\
& 2 & 100 & 100 \\
Ipasept & 0.2 & 0 & 0 \\
& 2 & 100 & 100 \\
Korsolin & 0.2 & 8 & 0 \\
& 1 & 100 & 100 \\
Menno-Ter-forte & 0.1 & 92 & 42 \\
& 10 & 100 & 100 \\
NaOCl & 1 & 75 & 100 \\
& & &
\end{tabular}

\section{Results}

In the laboratory experiment, all tested disinfectants were effective against Pythium sp. in peat debris when recommended concentrations were used. Even one minute treatment time was sufficient for all disinfectants except formaline and Virkon S. Menno-Ter-forte, Ipasept and Iobac P were effective against Pythium sp. (Table 3) at a lower than the recommended concentration.

Laboratory trials showed that Verticillium dahliae in peat debris was difficult to eradicate; only formaline was effective against this species. Virkon S and Menno-Ter-forte were also rather effective when the influence time was $60 \mathrm{~min}$. Iobac P and Ipasept were the weakest disinfectants (Table 4).

All the tested disinfectants were rather effective against Didymella bryoniae in plant debris at recommended concentrations when 10 min treatment time was used. Only $1 \%$ Iobac P did not eradicate completely D. bryoniae (Table 5).

Soaking the plastic pots contaminated with peat and fungus for 15-60 min in the disinfectant was sufficient to eradicate $D$. bryoniae and $P y$ thium sp. but not $V$. dahliae. However, Ipasept and Sanisept were ineffective against Pythium sp. and Ipasept against D. bryoniae (Table 6). V. dahliae was more difficult to eradicate than $P y$ thium sp. and D. bryoniae. However, Iobac P and $\mathrm{NaOCl}$ eradicated $V$. dahliae perfectly after 15 min treatment time. Also the effect of formaline, Korsolin and Menno-Ter-forte on this fungus was over $90 \%$ after 60 min treatment time (Table $6)$.

In the greenhouse experiment, disinfestation of Pythium sp. from the surface of plastic pots was the most successful with formaline, Iobac P, Korsolin, $\mathrm{NaOCl}$ and Menno-Ter-forte. Ipasept,

Table 6. The effect of disinfectants on fungi on the surface of plastic pots contaminated with peat-fungus mixture.

\begin{tabular}{|c|c|c|c|c|}
\hline Treatment & $\begin{array}{c}\text { Concentrations } \\
\%\end{array}$ & $\begin{array}{c}\text { Didymella } \\
\text { bryoniae }\end{array}$ & Pythium sp. & $\begin{array}{c}\text { Verticillium } \\
\text { dahliae }\end{array}$ \\
\hline & & \multicolumn{3}{|c|}{ Minimum time min/efficiency $\%$} \\
\hline Water & & $60 / 0$ & $60 / 50$ & $60 / 17$ \\
\hline Formaline & 5 & $15 / 100$ & $15 / 100$ & $60 / 92$ \\
\hline Iobac P & 3 & $15 / 100$ & $15 / 100$ & $15 / 100$ \\
\hline Ipasept & 2 & $60 / 58$ & $60 / 17$ & $60 / 83$ \\
\hline Korsolin & 1 & $15 / 100$ & $60 / 100$ & $60 / 100$ \\
\hline Menno-Ter-forte & 1 & $15 / 100$ & $60 / 92$ & $60 / 92$ \\
\hline $\mathrm{NaOCl}$ & 10 & $15 / 100$ & $60 / 100$ & $15 / 100$ \\
\hline Sanisept & 2 & $15 / 100$ & $60 / 42$ & $60 / 58$ \\
\hline Taloset & 3 & $60 / 92$ & - & $60 / 75$ \\
\hline Virkon $S$ & 2 & $15 / 100$ & $15 / 100$ & $60 / 75$ \\
\hline
\end{tabular}


Table 7. The effect of disinfectants on Pythium sp. in peat debris. Cucumber seedlings were used as test plants. Disease index: $0=$ healthy, $3=$ dead.

\begin{tabular}{|c|c|c|c|c|}
\hline \multirow[t]{2}{*}{ Treatment } & \multicolumn{2}{|c|}{ Disease index, 0-3 } & \multicolumn{2}{|c|}{ Efficiency \% } \\
\hline & Trial 1 & Trial 2 & Trial 1 & Trial 2 \\
\hline Healthy control & $0 \mathrm{a}$ & $0 \mathrm{a}$ & & \\
\hline Water & $2.60 \mathrm{~b}$ & $2.34 \mathrm{~b}$ & & \\
\hline Formaline & $=$ & $0.25 \mathrm{a}$ & - & 89 \\
\hline Iobac P & $0.15 \mathrm{a}$ & $0.10 \mathrm{a}$ & 94 & 96 \\
\hline Ipasept & $1.95 \mathrm{~b}$ & - & 25 & - \\
\hline Korsolin & $0.20 \mathrm{a}$ & - & 92 & - \\
\hline Menno-Ter-forte & $0.05 \mathrm{a}$ & $0.45 \mathrm{a}$ & 98 & 81 \\
\hline $\mathrm{NaOCl}$ & $0.05 \mathrm{a}$ & $0.60 \mathrm{a}$ & 98 & 74 \\
\hline Sanisept & $2.20 \mathrm{~b}$ & - & 15 & - \\
\hline Virkon S $1 \%$ & - & $1.88 \mathrm{~b}$ & - & 20 \\
\hline
\end{tabular}

F-values $\quad 58.98 * * * \quad 19.29 * * *$

Values in columns marked with the same letter do not differ at $\mathrm{P}=0.05$.

$* * *=\mathrm{P} 0.001$

Table 8. The effect of disinfection on Phomopsis sclerotioides in peat debris. Trials 1-2 lasted about 5 weeks, trials 3 and 4 until at fruit production. Disease index: $0=$ healthy roots, $3=$ dead roots. The effect of disinfectants was tested on cucumber.

\begin{tabular}{|c|c|c|c|c|c|}
\hline \multirow[t]{2}{*}{ Treatment } & \multicolumn{4}{|c|}{ Disease index, 0-3 } & \multirow{2}{*}{$\frac{\text { Efficiency } \%}{\text { Mean }}$} \\
\hline & Trial 1 & Trial 2 & Trial 3 & Trial 4 & \\
\hline Healthy control & $0.56 \mathrm{a}$ & $0.28 \mathrm{a}$ & $0 \mathrm{a}$ & $0 \mathrm{a}$ & \\
\hline Water & $1.50 \mathrm{~b}$ & $0.92 \mathrm{~b}$ & $2.56 \mathrm{c}$ & $3.00 \mathrm{c}$ & \\
\hline Formaline & $0.24 \mathrm{a}$ & $0.56 \mathrm{a}$ & $0.11 \mathrm{a}$ & $0.22 \mathrm{a}$ & 96 \\
\hline Iobac P & $1.43 \mathrm{~b}$ & $0.56 \mathrm{a}$ & $2.34 \mathrm{c}$ & $1.22 \mathrm{~b}$ & 34 \\
\hline Ipasept & - & - & - & $1.56 \mathrm{~b}$ & - \\
\hline Menno-Ter-forte & $0.45 \mathrm{a}$ & $0.61 \mathrm{a}$ & $0.67 \mathrm{a}$ & $0.33 \mathrm{a}$ & 83 \\
\hline $\mathrm{NaOCl}$ & $1.77 \mathrm{~b}$ & $0.45 \mathrm{a}$ & $2.22 \mathrm{c}$ & $0.94 \mathrm{a}$ & 36 \\
\hline Taloset & $1.24 \mathrm{~b}$ & $0.28 \mathrm{a}$ & - & $0.89 \mathrm{a}$ & 67 \\
\hline Virkon S (2 \%) & $0.22 \mathrm{a}$ & 0.56 a & $1.33 \mathrm{~b}$ & $0.44 \mathrm{a}$ & 76 \\
\hline F-values & $4.72 * *$ & $7.68 * * *$ & $31.5^{* * *}$ & $24.75^{* * *}$ & \\
\hline
\end{tabular}

Sanisept and Virkon S (1\%) were weakly effective against Pythium sp. (Table 7).

Phomopsis sclerotioides in the peat debris on the surface of plastic pots was eradicated by formaline in the greenhouse trial. Menno-Ter-forte and Virkon $\mathrm{S}$ were moderately effective against the fungus. The effect of Iobac $\mathrm{P}$ and $\mathrm{NaOCl}$ varied greatly in the different trials. They performed poorly in trials where the seedlings had been grown until fruit production (Table 8). The most effective disinfectants against $V$. dahliae in peat were formaline, Iobac $\mathrm{P}, \mathrm{NaOCl}$ and Virkon $\mathrm{S}$. Taloset was the least effective (Table 9).

$P$. sclerotioides was effectively eradicated from sand substrate by formaline and $\mathrm{NaOCl}$. Also Menno-Ter-forte was moderately effective. The least effective disinfectants against $P$. sclerotioides in sand were Virkon $\mathrm{S}$ and Taloset (Table 10). 
Table 9. The effect of disinfection on Verticillium dahliae in peat debris. Trials 1 and 2 lasted 6 weeks, trials 3 and 4 until fruit production. Results are based on laboratory cultures from the base pieces of cucumber seedlings. The effect of disinfectants was tested on cucumber.

\begin{tabular}{|c|c|c|c|c|c|}
\hline \multirow[t]{2}{*}{ Treatment } & \multicolumn{4}{|c|}{ Healthy plants \% } & \multirow{2}{*}{$\frac{\text { Efficiency \% }}{\text { Mean }}$} \\
\hline & Trial 1 & Trial 2 & Trial 3 & Trial 4 & \\
\hline Healthy control & $100.0 \mathrm{a}$ & $91.7 \mathrm{a}$ & $100.0 \mathrm{a}$ & $95.4 \mathrm{a}$ & \\
\hline Water & $61.1 \mathrm{ab}$ & $35.2 \mathrm{~b}$ & $66.7 \mathrm{~b}$ & $10.4 \mathrm{~b}$ & \\
\hline Desinfektol EL & - & - & - & 77.8 a & - \\
\hline Formaline & $88.9 \mathrm{ab}$ & $92.6 \mathrm{a}$ & $83.3 \mathrm{ab}$ & $83.6 \mathrm{a}$ & 82 \\
\hline Iobac P & $100.0 \mathrm{a}$ & $85.2 \mathrm{a}$ & $91.7 \mathrm{ab}$ & $73.2 \mathrm{a}$ & 83 \\
\hline Ipasept & $55.6 \mathrm{~b}$ & - & $88.9 \mathrm{ab}$ & - & - \\
\hline Menno-Ter-forte & $77.8 \mathrm{ab}$ & 86.1 a & $94.5 \mathrm{a}$ & $58.4 \mathrm{ab}$ & 67 \\
\hline $\mathrm{NaOCl}$ & $88.9 \mathrm{ab}$ & $95.4 \mathrm{a}$ & $86.1 \mathrm{ab}$ & $75.5 \mathrm{a}$ & 81 \\
\hline Taloset & $66.7 \mathrm{ab}$ & $88.0 \mathrm{a}$ & $77.8 \mathrm{ab}$ & $0 \mathrm{~b}$ & 28 \\
\hline Virkon S (2 \%) & $100.0 \mathrm{a}$ & $77.8 \mathrm{a}$ & $91.7 \mathrm{ab}$ & 82.9 a & 84 \\
\hline F-values & $3.17^{*}$ & $8.69 * * *$ & $3.08 *$ & $9.75^{* * *}$ & \\
\hline
\end{tabular}

Table 10. The effect of disinfection on Phomopsis sclerotioides in sand substrate. Disease index: $0=$ healthy roots, $3=$ dead roots. The effect of disinfectants was tested on cucumber.

\begin{tabular}{|c|c|c|c|c|c|}
\hline \multirow[t]{2}{*}{ Treatment } & \multicolumn{4}{|c|}{ Disease index, 0-3 } & \multirow{2}{*}{$\frac{\text { Efficiency } \%}{\text { Mean }}$} \\
\hline & Trial 1 & Trial 2 & Trial 3 & Mean & \\
\hline Healthy control & $0 \mathrm{a}$ & $0 \mathrm{a}$ & $0 \mathrm{a}$ & 0 & \\
\hline Water & $2.40 \mathrm{c}$ & $2.00 \mathrm{c}$ & $2.00 \mathrm{~b}$ & 2.13 & \\
\hline Desinfektol EL & - & $1.00 \mathrm{~b}$ & $0.53 \mathrm{ab}$ & 0.77 & - \\
\hline Formaline & $0.20 \mathrm{a}$ & $0.67 a b$ & $0.13 \mathrm{a}$ & 0.33 & 85 \\
\hline Iobac P & $0.40 \mathrm{a}$ & $0.89 \mathrm{~b}$ & $0.80 \mathrm{~b}$ & 0.70 & 67 \\
\hline Menno-Ter- forte & $0.40 \mathrm{a}$ & $0.78 \mathrm{ab}$ & $0.40 \mathrm{a}$ & 0.53 & 75 \\
\hline $\mathrm{NaOCl}$ & $0.40 \mathrm{a}$ & $0.22 \mathrm{ab}$ & $0.07 \mathrm{a}$ & 0.23 & 89 \\
\hline Taloset & $0.20 \mathrm{a}$ & $1.22 \mathrm{bc}$ & $1.27 \mathrm{~b}$ & 0.90 & 58 \\
\hline Virkon S (2\%) & $0.80 \mathrm{~b}$ & $1.33 \mathrm{bc}$ & $1.34 \mathrm{~b}$ & 1.16 & 46 \\
\hline
\end{tabular}

$\begin{array}{llll}\text { F-values } & 18.64^{* * *} & 11.09^{* * *} & 14.04^{* * * *}\end{array}$

Values in columns marked with the same letter do not differ at $\mathrm{P}=0.05$.

$* * *=\mathrm{P} 0.001$

The most effective preparations for disinfection of sand substrate from $V$. dahliae were formaline and $\mathrm{NaOCl}$. Iobac $\mathrm{P}$ was moderately effective. The least effective disinfectants were Taloset, Virkon S and Menno-Ter-forte. Desinfektol EL was equal to formaline in the first trial but ineffective in the second (Fig. 1).

\section{Discussion}

The laboratory trials showed that all disinfectants were effective against Pythium sp. in peat at $10 \mathrm{~min}$ treatment time. In the greenhouse trials trying to disinfect plastic pots and washing suspension from Pythium sp., only Ipasept, Sanisept and Virkon S 


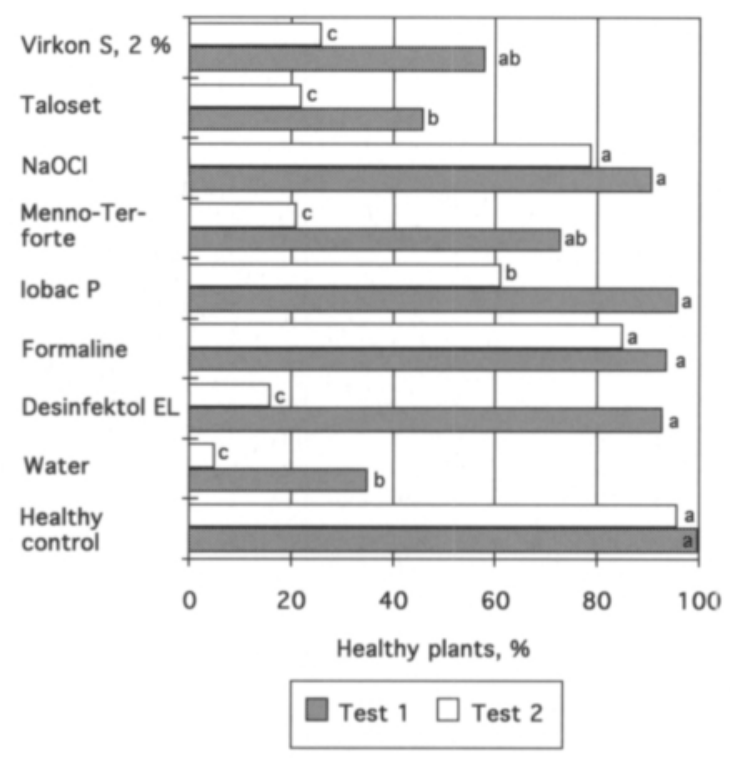

Fig. 1. The effect of disinfection on Verticillium dahliae in sand substrate. Bars marked with the same letter do not differ significantly at $\mathrm{P}=0.05$.

(1\%) were ineffective. The results are in accordance with the laboratory results of BAANDRUP (1983) and KOPONEN et al. (1992).

In the laboratory trials, Didymella bryoniae was easily eradicated at $10 \mathrm{~min}$ treatment time from peat debris. Only Iobac P was not effective against $D$. bryoniae because it was used a concentration of $1 \%$. Formaline, Menno-Ter-forte, Iobac P and Virkon $\mathrm{S}$ eradicated the fungus completely also from the surface of the plastic pots. According to KOPONEN et al. (1992), too, Menno-Ter-forte and $\mathrm{NaOCl}$ have yielded good result on plastic surfaces against $D$. bryoniae. This fungus has been effectively disinfested from wood surface and paper by formaline and Virkon S, respectively, (SUNDHEIM 1991). In agar tests carried out by JOHANSSON (1985), Korsolin (1\%) and Menno-Ter-forte $(0.5 \%)$ did not prevent the growth of $D$. bryoniae at $1 \mathrm{~min}$ treatment time. Also in this study Korsolin was ineffective against $D$. bryoniae on plastic surface.

In greenhouse trials only formaline was effective against Phomopsis sclerotioides mixed in peat. Menno-Ter-forte and Virkon S were moderately effective. $\mathrm{NaOCl}$, in addition to formaline, was effective against the fungus mixed in sand. However, SUNDHEIM (1989) has reported that formaline (as fumes or sprays) was not effective against $P$. sclerotioides in greenhouse experiment. In agar tests carried out in Sweden, Korsolin (1\%) and MennoTer-forte $(0.5 \%)$ did not inhibit the growth of $P$. sclerotioides after one minute influence time (JoHANSSON 1985). According to SUNDHEIM (1989), only formaline was effective against $P$. sclerotioides on wood pieces in laboratory test. According to SundHEIM (1991), Menno-Ter-forte was effective against $P$. sclerotioides in the paper test and Virkon $\mathrm{S}(1 \%)$ was ineffective. According to KOPONEN et al. (1992), many disinfectants (e.g. Menno-Terforte, $\mathrm{NaOCl}$, Virkon $\mathrm{S}$ ) need at least 60 min exposure time against $P$. sclerotioides to reach over $95 \%$ effect in laboratory circumstances.

The laboratory tests showed that only formaline was effective against $V$. dahliae in peat debris. Iobac $\mathrm{P}$, Korsolin and $\mathrm{NaOCl}$ eradicated the fungus completely from the surface of plastic pots. According to BRIELMAIER (1985), Menno-Ter-forte has been effective against $V$. dahliae after $10 \mathrm{~min}$ influence time in a laboratory experiment, but in this study Menno-Ter-forte gave $92 \%$ effect after $60 \mathrm{~min}$ on plastic surface. According to KOPONEN et al. (1992), Desinfectol EL, Menno-Ter-forte and $\mathrm{NaOCl}$ were effective against $V$. dahliae on synthetic cloth and plastic surface after $60 \mathrm{~min}$ influence time in a laboratory test.

In greenhouse trials formaline, Iobac $\mathrm{P}, \mathrm{NaOCl}$ and Virkon $\mathrm{S}$ were effective against $V$. dahliae in peat debris. Formaline and $\mathrm{NaOCl}$ were the most effective against the fungus in sand. The effect of Iobac P and Desinfectol EL varied in different trials. Menno-Ter-forte and Virkon S were ineffective against $V$. dahliae. In the greenhouse trials the effect of disinfectants varied in different trials. None of the disinfectants eradicated $V$. dahliae totally from peat debris. The most effective disinfectants against $V$. dahliae in peat debris were formaline, Iobac $\mathrm{P}, \mathrm{NaOCl}$ and Virkon S. V. dahliae in sand substrate were eradicated most effectively by formaline and $\mathrm{NaOCl}$. The effect of Iobac P and Desinfectol EL varied in different trials.

The results show that all the tested disinfectants 
are effective against Pythium sp. and Didymella bryoniae. The effect of Ipasept, Sanisept and Korsolin varied. Virkon $\mathrm{S}$ should be used at concentrations of at least $2 \%$. Formaline is the most effective against Phomopsis sclerotioides and Verticillium dahliae.
Although a treatment time of 10 or 15 min was sufficient for most disinfectants to kill the fungi in the laboratory, a disinfection time of at least $60 \mathrm{~min}$ is recommended in practice.

\section{References}

BAANDRUP, M. 1983. Desinfektionsmidler. Specialrapport vid Köpenhamns universitet (Ref. Johansson 1985).

BooтH, C. 1971. Methods in microbiology. 795 p. Vol 4. Academic Press, London.

Bочнот, D. 1975a. Recherches sur I' écologie des champignons parasites dans le sol. V Une tecnique sélective d'estimation du potentiel infectieux des sols, terreaux et substrates infestés par Pythium sp., études qualitatives. Ann. Phytopath. 7: 9-18.

- 1975b. Recherches sur l' écologie des champignons parasites dans le sol. VIII Quantification de la tecnique d'estimation du potentiel infectieux des sols, terreaux et substrates, infestés par Pythium sp. Ann. Phytopath. 7: 147 154.

BRIELMAIER, U. 1985. Wirkung von Desinfektionsmitteln auf pilzliche Krankheitserreger, die im Zierpflanzenbau von Bedeutung sind. Meded. Fac. Landbouww. Rijksuniv. Gent 50/3b: 1235-1242.

Domsch, K. H., Gams, W. \& Anderson, T.-H. 1980. Compendium of soil fungi. Vol. 1. Academic Press, London. $859 \mathrm{p}$.

FLETCHER, J. T. 1984. Diseases of greenhouse plants. 351 p. Longman, London.

JoHANSSON, A.-K. 1985. Löpande desinfektion i växthus av Xanthomonas pelargonii och $X$. begoniae. Disinfektion in greenhouses of Xanthomonas pelargonii and $X$. begoniae. Institutionen för växt- och skogsskydd. (Sveriges Lantbr. Univ.) Examensarbeten 1985 (5) Uppsala. 67 p.

Koponen, H., Avikainen, H. \& Tahvonen, R. 1992. The effect of disinfectants on fungi in pure culture and on different surface materials. Agric Sci. Finl. 1:587-596.

-, Avikainen, H. \& Tahvonen, R. 1993. The effect of disinfectants on fungal diseases of potato and vegetables. Agric. Sci. Finl. 2: 169-177.

Linnasalmi, A. 1955. Maan desinfiointi. Puutarhaviljelijäin liiton julkaisuja no. 111. Helsinki. 46 p.

Murman, T. 1992. Kasvihuonekurkun viljely. Kauppapuutarhaliitto. Helsinki. 139 p.

Sundheim. L. 1989. Desinfeksjonsmiddel mot soppar. Akt. Stat. Fagtj. Landbr. 3: 89-95.

- 1991. Reingering og desinfeksjon mot sjukdomar i veksthus. Plantevern i veksthus. Etterutdanninngskurs arrangert av statens fagtjeneste for landbruket 5. februar 1991. Mimeogr 5 p.

TAHVONEN, R. 1987. Lehtihometta ja lakastumista, kurkun kaksi uutta tautia. Koetoiminta ja käytäntö 44: 29.

Manuscript received July 1992

Hanna Avikainen

Risto Tahvonen

Agricultural Research Centre of Finland

Institute of Plant Protection

FIN-31600 Jokioinen, Finland

Hilkka Koponen

Department of Plant Biology

P.O.Box 28

FIN-00014 University of Helsinki, Finland 


\title{
SELOSTUS
}

\section{Desinfiointiaineiden teho kurkun sienitauteihin}

\section{Hanna AVikainen, HilkKa KoPONEn ja Risto TAHVONEN}

\author{
Maatalouden tutkimuskeskus ja Helsingin yliopisto
}

Kymmenen desinfiointiaineen tehoa kurkun Didymella bryoniae-, Pythium sp.-, Phomopsis sclerotioides- ja Verticillium dahliae - tauteja vastaan testattiin laboratorio ja kasvihuoneolosuhteissa vuosina 1988-1990. Tutkittavat valmisteet olivat Desinfektol EL (etanoli), formaliini (formaldehydi), Iobac P (jodi), Ipasept, Menno-Ter-forte ja Sanisept ja Taloset (kvartaarisia ammoniumyhdisteitä), Korsolin (glutaraldehydi), natriumhypokloridi (aktiivinen kloori) ja Virkon S (kaliumperoksisulfaatti),

Laboratoriotesteissä testattiin valmisteiden suositeltujen käyttöväkevyyksien ja niistä tehtyjen laimennosten tehoa turpeessa tai kasvijätteissä oleviin taudinaiheuttajiin. Lisäksi tutkittiin käsittelyajan vaikutusta valmisteiden tehoon. Kasvihuonetesteissä kasvatettiin kurkun taimia sienillä infektoidulla turpeella liatuissa, desinfioiduissa muoviruukuissa. Valmisteiden tehoa testattiin myös Phomopsis- ja Verticillium - sienillä infektoidun hiekka-alustan desinfioinnissa.

Pythium-sienen aiheuttamaan kurkuntaimipolte- ja tyvitautiin tehosivat hyvin formaliini, Iobac $\mathrm{P}, \mathrm{NaOCl}$, Korsolin ja Menno-Ter-forte. Heikkoja valmisteita olivat Ipasept, Sanisept ja Virkon S (1\%). Formaliini oli tehokkain kurkunmustajuurimädän (Phomopsis sclerotioides) desinfioinnissa. Hiekka-alustalla oleva sieni voitiin hävittää myös $\mathrm{NaOCl}$ :lla. Verticillium-sienen aiheuttama kurkunlakastumistauti torjuttiin parhaiten formaliinilla, Iobac P:llä, $\mathrm{NaOCl}$ :lla ja Virkon S:Ilä. Hiekan joukossa olevaan taudinaiheuttajaan tehosivat formaliini ja $\mathrm{NaOCl}$. Didymella bryoniae oli herkkä useimmille tutkituille desinfiointiaineille.

Desinfiointiajaksi suositellaan vähintään tunnin käsittelyaikaa, vaikka lyhyempikin aika laboratoriotesteissä saattoi antaa hyvän tuloksen. 